\title{
Journal And Confrence Paper On (Enviornment) E - Waste Management
}

\author{
M.D. Jalal Uddin \\ Asst professor civil Dept
}

\begin{abstract}
The electronic industry is the world's largest and fastest growing manufacturing industry in the world. Discarded electronic and electrical equipment with all of their peripherals at the end of life is termed ewaste. The quantity of c-waste generated in developed countries equals $1 \%$ of total solid waste on an average and is expected to grow to $2 \%$ by 2011 and is one of the fastest growing waste streams.E-waste consists of ferrous and non ferrous metals, plastic, glass, ceramics, rubber etc. E-waste is valuable source for secondary raw material but harmful if treated and discarded improperly as it contains many toxic components such as lead, cadmium, mercury, polychiorinated biphenlys etc. The presence of lead, mercury, arsenic, cadmium, selenium and hexavalent chromium and flame retardants beyond threshold quantities in e-waste classifies them as hazardous wastes.
\end{abstract}

Rather than recycle the c-waste generated, the developed countries are finding easy way out of the problem by exporting them to developing economies. Recycling c-waste in a crude manner, as is done now will lead environmental pollution. A review of the study conducted of uncontrolled dumping and crude recycling of cwaste reveals the gravity of the problem. Technologies are suggested for environmentally sound management of $c$-waste. Legislation is the need of the hour for enforcing environmentally sound management.

"Today's gadgets are tomorrows E-waste." 95 percent of electronic waste is recyclable. However, unregulated recycling can cause more harm to the environment than landfilling. While many companies, have safe and effective recycling programs, the majority of recycling companies export some percentage of their electronic waste to China or poor countries in Africa, where the waste is "recycled," or destroyed and stripped of its valuable metals. Though this seems like a good thing on the surface, because components are being repurposed, unregulated recycling centers burn or dissolve the plastic components to release the precious metals: a process that releases environmental contaminants into the air, land, and water that would otherwise remain trapped and inert in landfills.

The major portion of the c-waste generated domestically as well as illegally imported are recycled in crude manner leading to pollution of the environment. Lack of legislation in our country at present is aiding this hazardous form of recycling. Therefore there is urgent need to frame and implement rules for regulating this waste and to find environmentally sound, economically viable methods for recycling and disposing of this necessary evil. The necessity of environmentally sound management of c-waste is brought out with the help of a case study of uncontrolled dumping of c-waste. we have collected data of disposed materials percentage in Mahbubnagar and which is causing harm to environment and for reducing this we have explained some techniques from which it can be controlled without causing any effects to environment.

Keywords : E-waste, composition, recycle potential, control techniques.

I.

WHAT IS E-WASTE?

E-waste is a popular, informal name for electronic products nearing the end of their "useful life." Common electronic products include: 


\section{* WHY IS E-WASTE HARMFUL?}

E-waste can contain hazardous materials such as lead, mercury, and hexavalent chromium, in circuit boards, batteries, and color cathode ray tubes (CRTs). Televisions and CRT monitors contain four pounds of lead on average (the exact amount depends on size and make). Electonics have been cited as a leading source of mercury in municipal waste. In addition, brominated flame retardants, now mostly banned in Europe due to their toxicity and persistence, are commonly added to plastics used in electronics. If improperly handled, these toxics can be released into the environment, potentially placing our health and subsistence resources at risk.

\section{* Where did this begin?}

The term electronic waste is only a recent entity, as devices of higher technology only began to be produced towards the latter half of the 20th century. Before the 1970s, there was little production of these technologically complicated items, each consisting of over 1,000 different substances, several of which are toxic and create serious pollution upon disposal. (BAN, 2002) Each year, more new devices are created, and more new devices are thrown out. This began in the most developed nations such as the United States and Japan, leading the technological revolution but also leading the electronic pollution revolution as well. And with an immense population,America

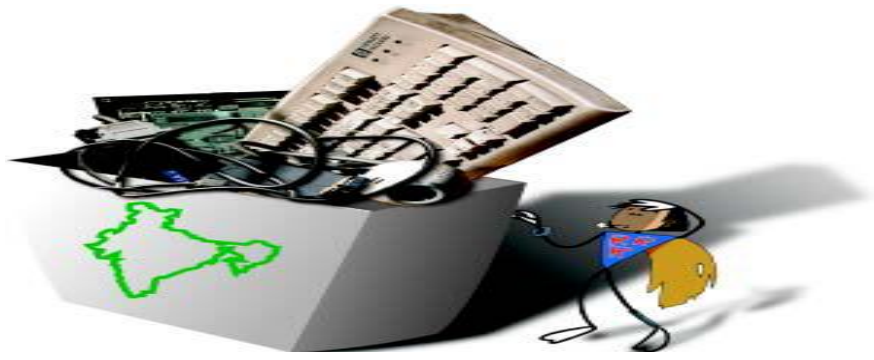

II. CHAPTER

\section{MAJOR SOURCES:-}

* Individuals and Small Businesses: The useful span of a computer has come down to about two years due to improved versions being launched about every 18 months. Often, new software is incompatible or insufficient with older hardware so that customers are forced to buy new computers. Large corporations, Institutions and Government: Large users upgrade employee computers regularly.

* Original Equipment Manufacturers (OEMs):OEMs generate e-waste when units coming off the production line do not meet quality standards, and must be disposed off. Some of the computer manufacturers contract with recycling companies to handle their electronic waste, which often is exported.

* Besides computers, other major e waste source is the cellular phone., refregirators ,ovens,switchboards,airconditioner, batteries, tv etc.

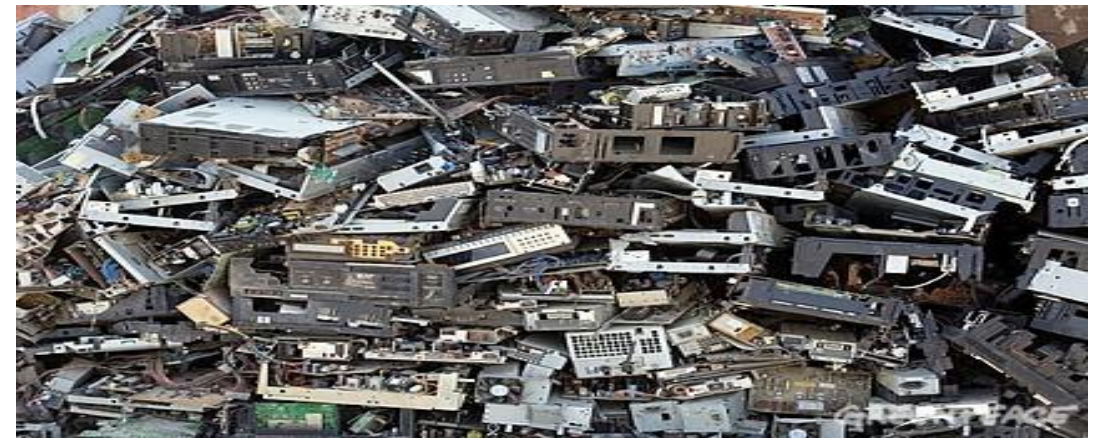

ELECTRONIC APPLICENCES

\section{CLASSIFICATION OF E-WASTE \\ * COMPONENTSOF E-WASTE:-}

III. CHAPTER

E-waste has been categorized into three main categories, viz. large household appliances, IT and Telecom and consumer equipment. Refrigerator and washing machine represent large household appliances, personal computer monitor and laptop represent IT and Telecom, while television represents consumer equipment. Each of these e-waste items has been classified with respect to twenty six common components, which could be found in them. These components form the "building blocks" of each item and therefore they are readily "identifiable" and "removable". These components are 
- metal,

- motor/compressor,

- cooling, plastic,

- insulation,

- glass, (Liquid Crystal Display) LCD,

- rubber, wiring/ electrical,

- transformer,

- magnetron,

- textile,

- circuit board,

- fluorescent lamp, incandescent lamp,

- heating element, thermostat,

- BFR-containing plastic, batteries,

- fluorocarbons (CFC/HCFC/HFC/HC),

- external electric cables,

- refractory ceramic fibers,

radioactive substances and electrolyte capacitors. The kinds of components, which are found in refrigerator, washing machine, personal computers (PC) and televisions, are shown in given figures.

From this figures it can be seen that the range of different items seen in e-waste is diverse. However, e-waste from these items can be dismantled into relatively smaller number of common components for further treatments.

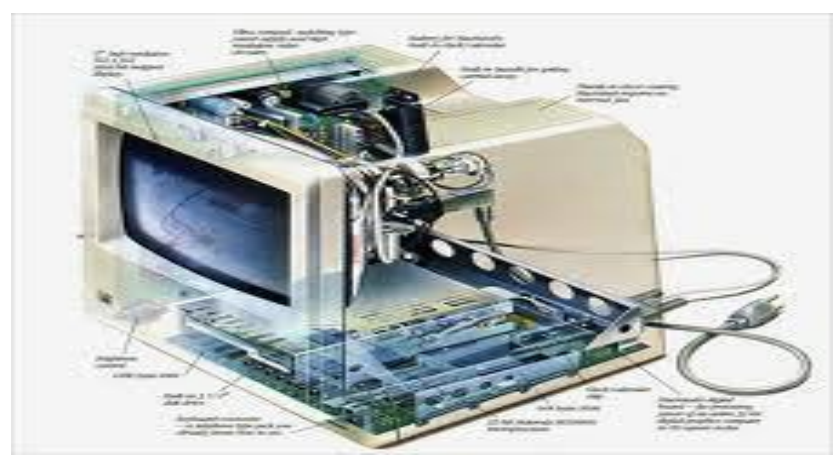

COMPUTER PARTS
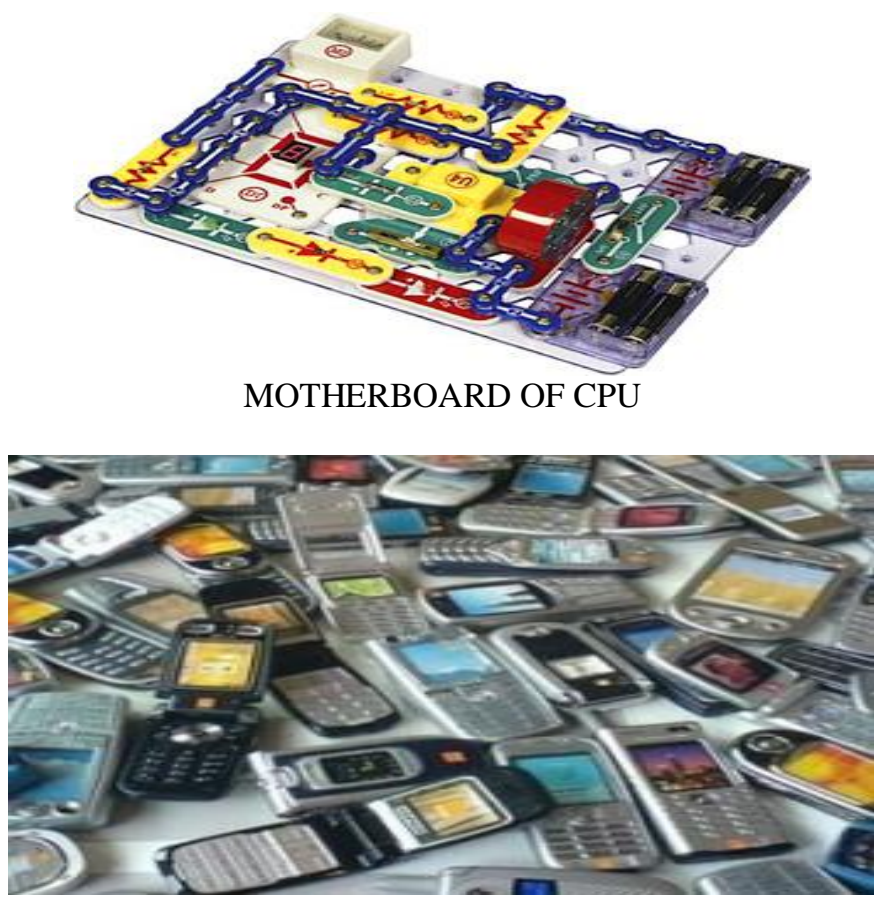

CELLULAR PHONES 


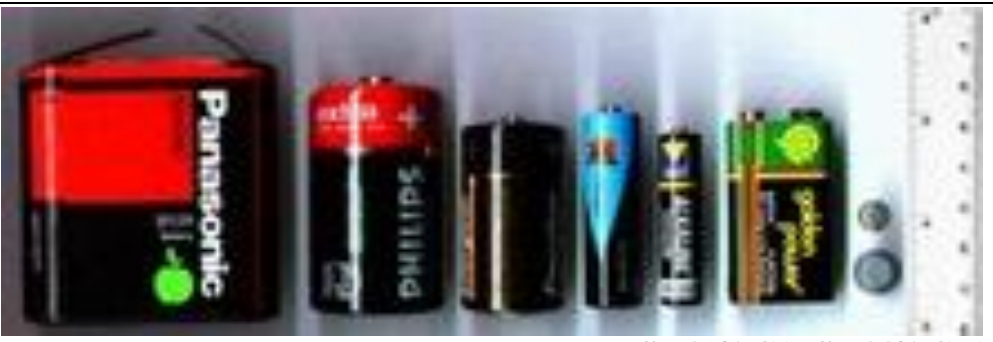

BATTERIES 4.5-Volt, D, C, AA, AAA, 9-Volt, SR41/AG3, SR44/AG13 cell

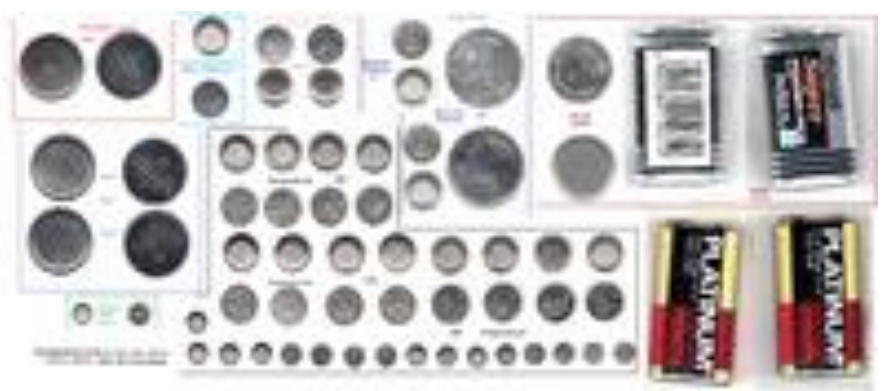

WASHING MACHINES
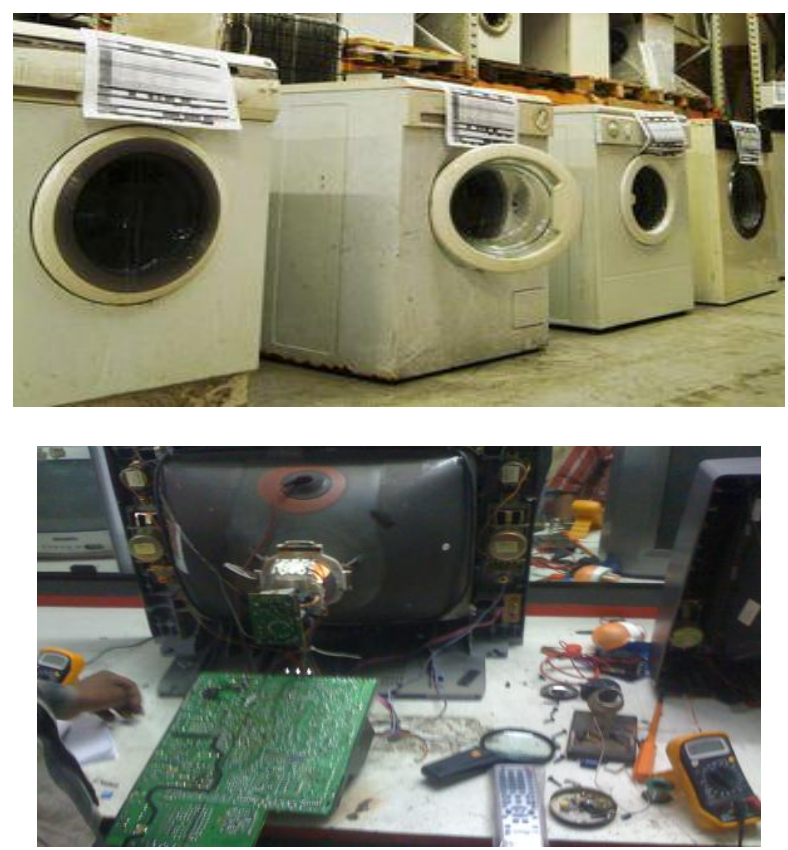

TELEVISION PARTS

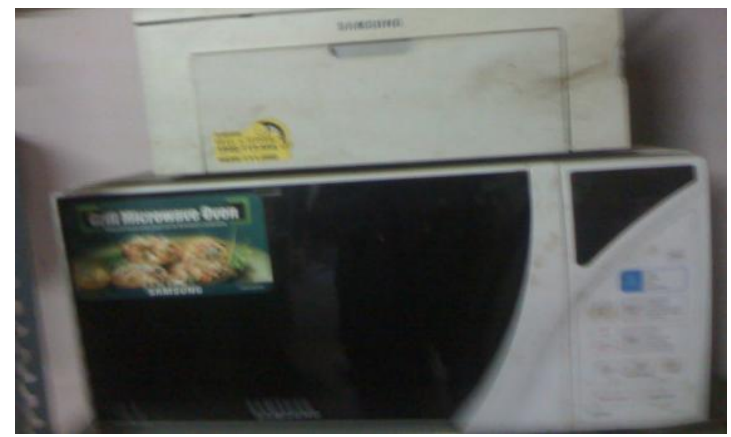

OVENS 


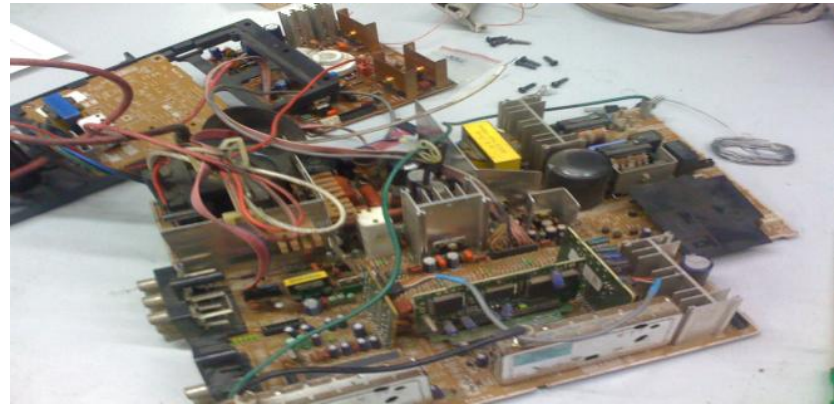

ELECTRÓNIC BOARDS

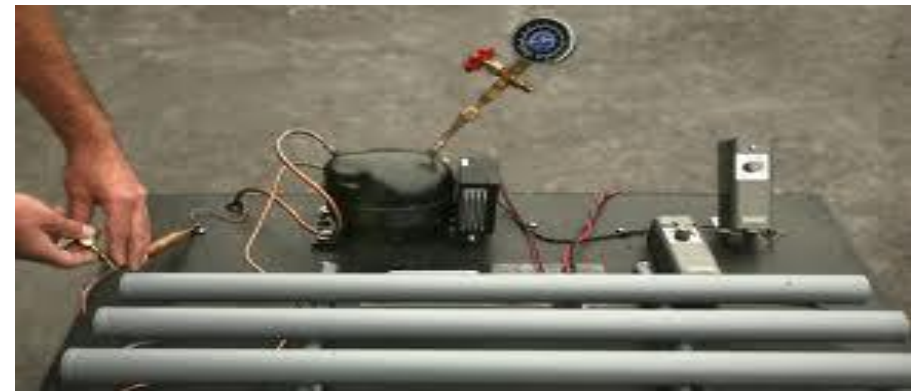

REFREGIRATOR PUMP

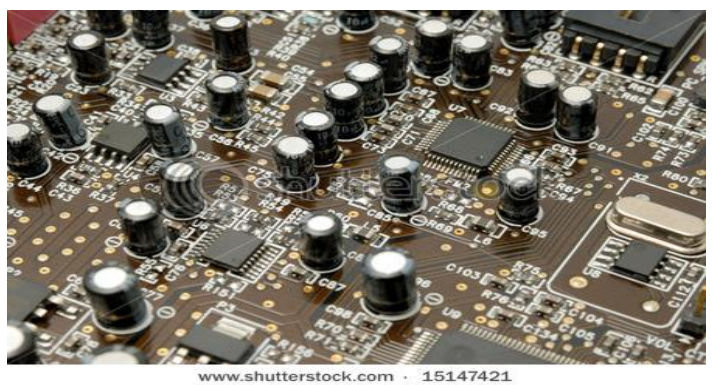

SWITCH BOARD WITH CAPACITOR

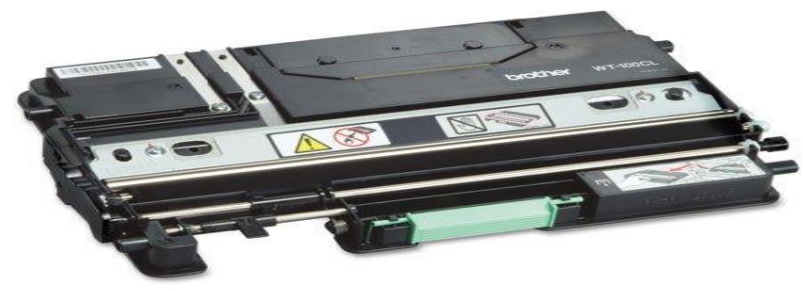

PRINTER

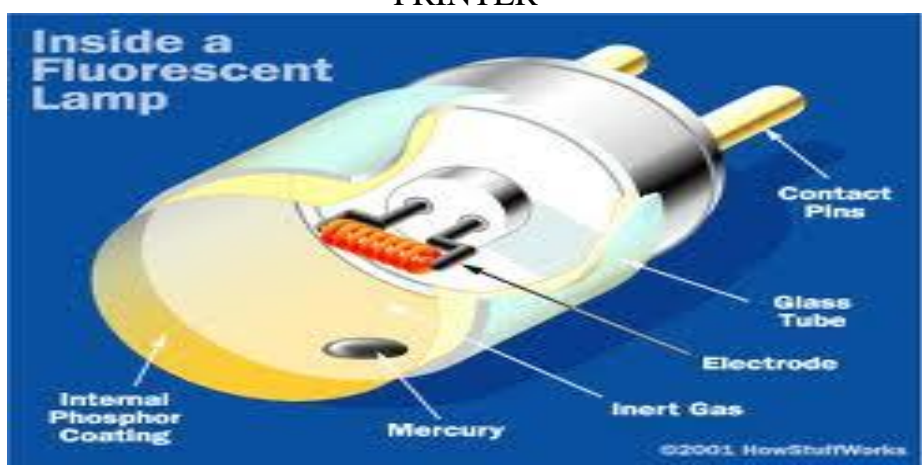

FLUORESCENT LAMP 


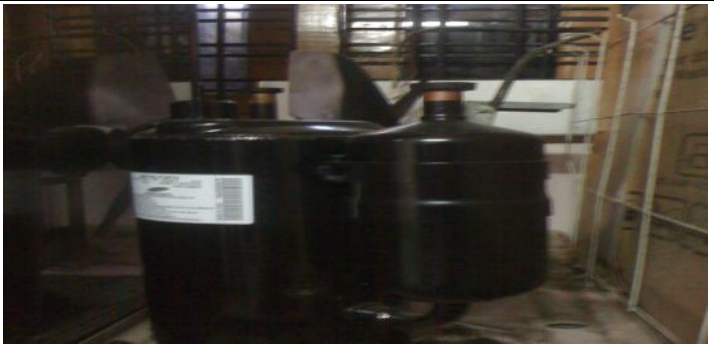

REFRIGERATOR PUMP

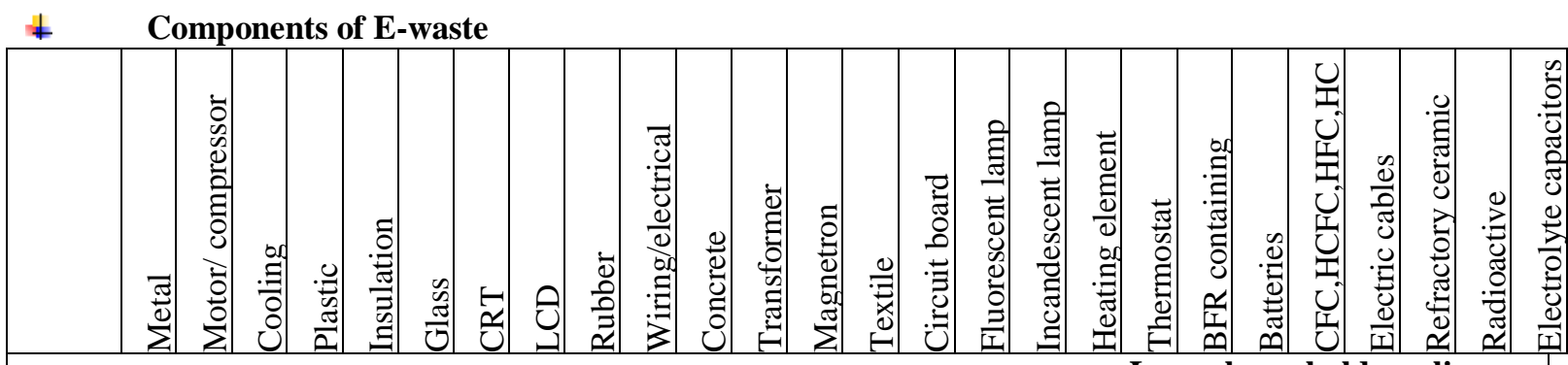

Large household appliances
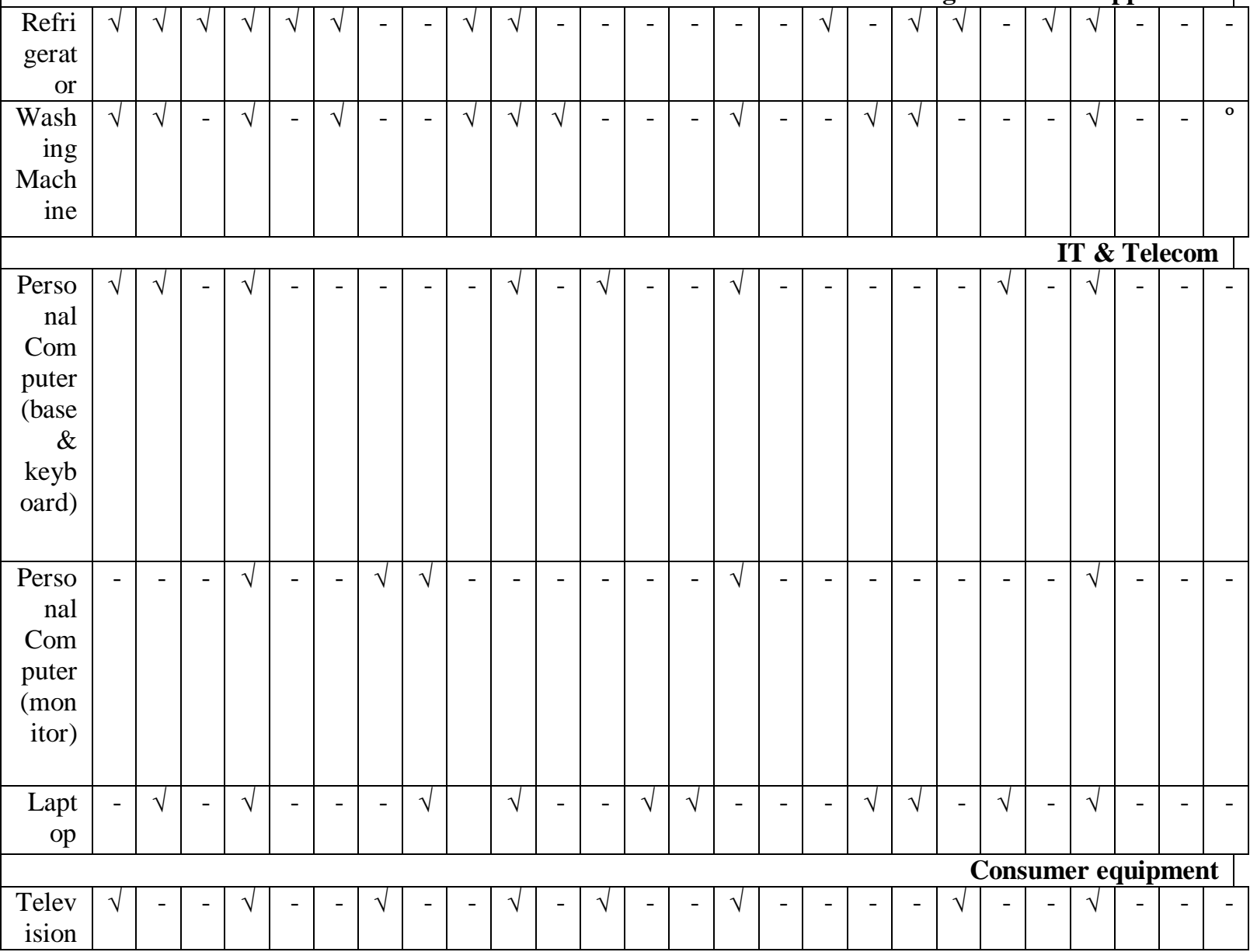

\section{* COMPOSITION OF E-WASTE:-}

Composition of e-waste is very diverse and differs in products across different categories. It contains more than 1000 different substances, which fall under "hazardous" and "non-hazardous" categories. Broadly, it consists of ferrous and non-ferrous metals, plastics, glass, wood \& plywood, printed circuit boards, concrete and ceramics, rubber and other items. Iron and steel constitutes about50\% of the e-waste followed by plastics (21\%), non ferrous metals $(13 \%)$ and other constituents. Non-ferrous metals consist of metals like copper, aluminium and precious metals e.g. silver, gold, platinum, palladium etc. The presence of elements like lead, mercury, arsenic, cadmium, selenium and hexavalent chromium and flame retardants beyond threshold 
quantities in e-waste classifies them as hazardous waste. The possible constituents of concern found in the three main categories described in given table.

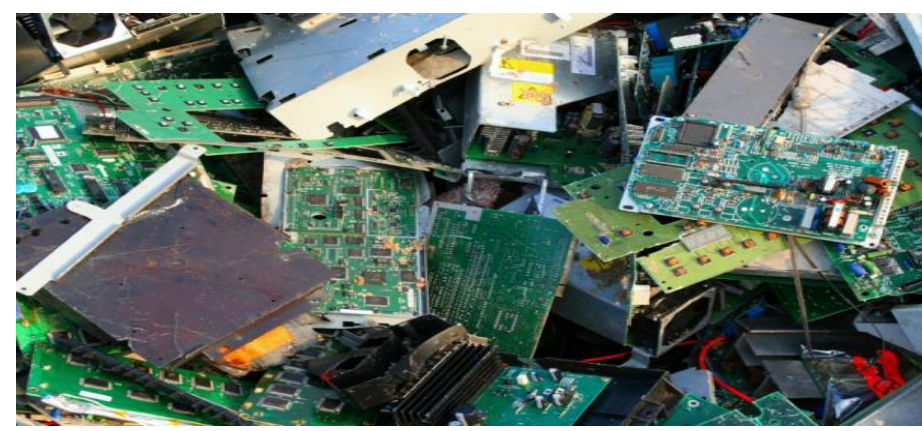

Possible Hazardous Substances in Components of E-waste:-

The

\begin{tabular}{|l|l|}
\hline Component & Possible hazardous content \\
\hline Metal & \\
\hline Motor/compressor & \\
\hline Cooling & Ozone Depleting Substances (ODS) \\
\hline Plastic & Phthalate plasticizer, brominated flame retardants (BFR) \\
\hline Insulation & Insulation ODS in foam, asbestos, refractory ceramic fiber \\
\hline Glass & \\
\hline Cathode Ray Tube & Lead, Antimony, Mercury, Phosphor \\
\hline Liquid Crystal Display & Mercury \\
\hline Rubber & Phthalate plasticizer, BFR \\
\hline Wiring / electrical & Phthalate plasticizer, BFR, Lead \\
\hline & \\
\hline Transformer & \\
\hline Circuit Board & Lead, Beryllium, Antimony, BFR \\
\hline Fluorescent lamp & Mercury, Phosphorous, Flame retardants \\
\hline Incandescent lamp & \\
\hline Heating element & \\
\hline Thermostat & Mercury \\
\hline BFR-containing plastic & BFRs \\
\hline Batteries & Lead, Lithium, Cadmium, Mercury \\
\hline CFC,HCFC,HFC,HC & ODS \\
\hline External electric cables & BFRs, plasticizers \\
\hline Electrolyte capacitors & Glycol, other unknown substances \\
& \\
\hline
\end{tabular}

substances within the above mentioned components, which cause most concern are the heavy metals such as lead, mercury, cadmium and chromium(VI), halogenated substances (e.g. CFCs), polychlorinated biphenyls, plastics and circuit boards that contain brominated flame retardants (BFRs). BFR can give rise to dioxins and furans during incineration. Other materials and substances that can be present are arsenic, asbestos, nickel and copper. These substances may act as catalysts to increase the formation of dioxins during incineration.

\section{CHAPTER}

HEALTH EFFECTS OF SOME COMMON CONSTITUENTS IN E-WASTE:-

The health effects of heavy metals and certain compounds found commonly in components of e-waste are described below: 


\section{\$ Lead}

Lead is used in glass panels and gaskets in computer monitors and in solder in printed circuit boards and other components. Lead causes damage to the central and peripheral nervous systems, blood systems, kidney and reproductive system in humans. It also affects the endocrine system, and impedes brain development among children. Lead tends to accumulate in the environment and has high acute and chronic effects on plants, animals and micro organisms (Metcalf \& Eddy,2003).

\section{Cadmium}

Cadmium occurs in surface mounted device (SMD) chip resistors, infra-red detectors, and semiconductor chips. Some older cathode ray tubes contain cadmium. Toxic cadmium compounds accumulate in the human body, especially the liver, kidneys pancreas, thyroid (Metcalf \& Eddy, 2003, Basel Action Network, 2002).

\section{* Mercury}

It is estimated that $22 \%$ of the yearly world consumption of mercury is used in electrical and electronic equipment. Mercury is used in thermostats, sensors, relays, switches, medical equipment, lamps, mobile phones and in batteries. Mercury, used in flat panel displays, will likely increase as their use replaces cathode ray tubes.

Mercury can cause damage to central nervous system as well as the foetus. The developing foetus is highly vulnerable to mercury exposure (Metcalf \& Eddy, 2003). When inorganic mercury spreads out in the water, it is transformed to methylated mercury which bio-accumulates in living organisms and concentrates through the food chain, particularly via fish (Basel Action Network, 2002).

\section{* Hexavalent Chromium/Chromium VI}

Chromium VI is used as corrosion protector of untreated and galvanized steel plates and as a decorative or hardener for steel housings. Chromium VI can cause damage to DNA and is extremely toxic in the environment. Long term effects are skin sensitization and kidney damage(Metcalf \& Eddy, 2003).

\section{* Plastics (including PVC)}

The largest volume of plastics (26\%) used in electronics has been poly vinyl chloride (PVC). PVC elements are found in cabling and computer housings. Many computer moldings are now made with the somewhat more benign acrylonitrile butadiene (ABS) plastic. Dioxins are released when PVC is burned (Basel Action Network, 2002)..

\section{* Brominated Flame Retardants (BFRs)}

BFRs are used in the plastic housings of electronic equipment and in circuit boards to prevent flammability. BFRs are persistent in the atmosphere and show bioaccumulation. Concerns are raised considering their potential to toxicity (Basel Action Network, 2002).

\section{* Barium}

Barium is a soft silvery-white metal that is usedprotect users from radiation.

Studies have shown that short-term exposure to barium causes brain swelling, muscle weakness, damage to the heart, liver, and spleen(Basel Action Network, 2002).

\section{\$ Beryllium}

Beryllium is commonly found on motherboards and finger clips. Exposure to beryllium can cause lung cancer. Beryllium also causes a skin disease that is characterised by poor wound healing and wartlike bumps. Studies have shown that people can develop beryllium disease many years following the last exposure. It is used as a copper-beryllium alloy to strengthen connectors.

Barium is a soft silvery-white metal that is used to protect users from radiation.

\section{* Phosphor and additives}

Phosphor is an inorganic chemical compound that is applied as a coat on the interior of the CRT faceplate. Phosphor affects the display resolution and luminance of the images that is seen in the monitor.

The phosphor coating on cathode ray tubes contains heavy metals, such as cadmium, and other rare earth metals, for example, zinc, vanadium as additives. These metals and their compounds are very toxic. This is a serious hazard posed for those who dismantle CRTs by hand. 


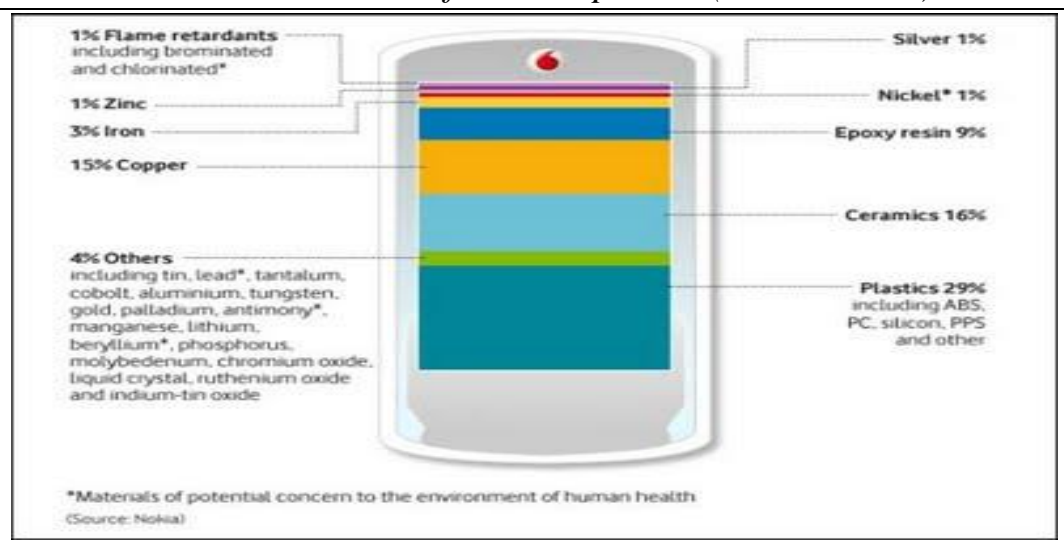

\section{The Environmental Impact :-}

\section{* NEED FOR GUIDELINES FOR ENVIRONMENTALLY SOUND MANAGEMENT-}

The saying waste is misplaced wealth is true in the case of e-waste. The recyclability of e-waste and the precious metals that can be extracted from the waste make recycling a lucrative business. But recycling using environmentally sound means costly business and so majority of the e-waste is recycled via the informal sector. Informal recycling involves minimal use of technology and is carried out in the poorer parts of big cities. The standard recycling drill involves physically breaking down components often without any protective gear, burning poly vinyl chloride (PVC) wires to retrieve copper, melting of lead and mercury laden parts. The extraction of gold and copper requires acid processing. The plastic parts, which contain brominated flame retardants (BFR) are also broken into small pieces prior to recycle. All these processes release toxic fumes into the atmosphere and polluted water into soil and water bodies leading to contamination. Most of those who work in the recycling sector are the urban poor with low literacy lacking awareness of the hazards of the toxic ewastes. Children and women are routinely involved in the operations. Most of the work is done by bare hands. Waste components which do not have resale value are openly burnt or disposed off in open dumps

Rapid pace of product obsolescence resulting in short life span of computers and other electronic equipments coupled with exponential increase in consumption of such products will result in the doubling of waste over next five to six years. The toxicity of constituents in e-waste, lack of environmentally sound recycling infrastructure and the large scale current practice of informal recycling highlight the urgent need for guidelines for environmentally sound management of e-waste.

\section{CHAPTER}

\section{METHODOLOGY FOR ENVIRONMENTALLY SOUND MANAGEMENT}

\section{* E-WASTE COMPOSITION AND RECYCLE POTENTIAL:-}

The composition of e-waste and its recyclable potential is specific for each appliance. In order to handle this complexity, the parts/materials found in e-waste may be divided broadly into six categories as follows:

Iron and steel, used for casings and frames

Non-ferrous metals, especially copper used in cables, and aluminum

Glass used for screens, windows

Plastic used as casing, in cables and for circuit boards

Electronic components

Others (rubber, wood, ceramic etc.)

Overview of the composition of the appliances in the three categories mentioned earlier is given in table .

\begin{tabular}{|l||l||l||l|l|l||l|l|}
\hline Appliances & $\begin{array}{l}\text { Average } \\
\text { weight } \\
\text { (kg) }\end{array}$ & $\begin{array}{l}\text { Fe \% } \\
\text { weight }\end{array}$ & $\begin{array}{l}\text { Non Fe- } \\
\text { metal \% } \\
\text { weight }\end{array}$ & $\begin{array}{l}\text { Glass \% } \\
\text { weight }\end{array}$ & $\begin{array}{l}\text { Plastic \% \% } \\
\text { weight }\end{array}$ & $\begin{array}{l}\text { Electronic } \\
\text { components \% } \\
\text { weight }\end{array}$ & $\begin{array}{l}\text { Others } \\
\text { \% weight }\end{array}$ \\
\hline $\begin{array}{l}\text { Refrigerators and } \\
\text { freezers }\end{array}$ & 48.0 & 64.4 & 6.0 & 1.4 & 13.0 & 0.2 & 15.0 \\
\hline \hline Personal computer & 29.6 & 20.0 & 24 & 15 & 23.0 & 17.3 & 0.7 \\
\hline TV sets & 36.2 & 5.3 & 5.4 & 62 & 22.9 & 0.9 & 3.5 \\
\hline
\end{tabular}


Journal And Confrence Paper On (Enviornment) E-Waste Management

The recovery potential (typical values) of items of economic value from refrigerator, personal computer and television are given in tables

Recoverable Quantity of Materials in a Refrigerator:-

\begin{tabular}{|l|l|}
\hline Material Type & $\begin{array}{l}\text { \% (by } \\
\text { weight) }\end{array}$ \\
\hline \hline CFCs & 0.20 \\
\hline \hline Oil & 0.32 \\
\hline Ferrous Metals & 46.61 \\
\hline \hline Non-Ferrous Metals & 4.97 \\
\hline Plastics & 13.84 \\
\hline \hline Compressors & 23.80 \\
\hline \hline Cables/Plugs & 0.55 \\
\hline Spent Foam & 7.60 \\
\hline \hline Glass & 0.81 \\
\hline \hline Mixed Waste & 1.30 \\
\hline \hline Total & 100.00 \\
\hline
\end{tabular}

REFRIGERATOR COMPRNIENTS·-

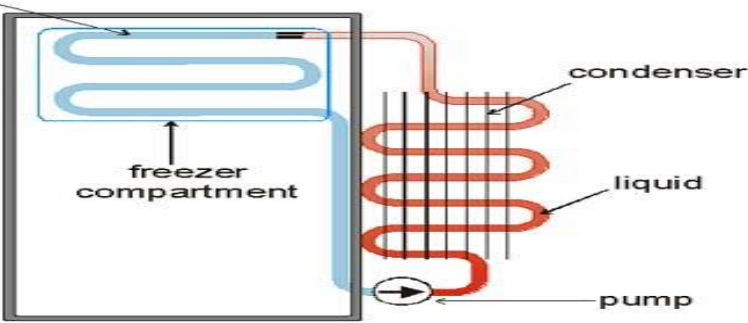

Recoverable Quantity of Materials in a Personal Computer:-

\begin{tabular}{|c|c|c||c|c|}
\hline Elements & $\begin{array}{c}\text { Content (\% of } \\
\text { total weight) }\end{array}$ & $\begin{array}{c}\text { Content } \\
(\mathbf{K g})\end{array}$ & $\begin{array}{c}\text { Recycling } \\
\text { efficiency (\%) }\end{array}$ & $\begin{array}{c}\text { Recoverable weight of } \\
\text { element (kg) }\end{array}$ \\
\hline Plastics & 23 & 6.25 & $20 \%$ & 1.251 \\
\hline Lead & 6 & 1.71 & $5 \%$ & 0.086 \\
\hline Aluminum & 14 & 3.85 & $80 \%$ & 3.084 \\
\hline Germanium & 0.0016 & 0.00 & $0 \%$ & 0 \\
\hline Gallium & 0.0013 & 0.00 & $0 \%$ & 0 \\
\hline Iron & 20 & 5.57 & $80 \%$ & 4.455 \\
\hline Tin & 1 & 0.27 & $70 \%$ & 0.192 \\
\hline Copper & 7 & 1.88 & $90 \%$ & 1.696 \\
\hline Barium & 0.0315 & 0.01 & $0 \%$ & 0 \\
\hline Nickel & 0.8503 & 0.23 & $0 \%$ & 0 \\
\hline Zinc & 2 & 0.60 & $60 \%$ & 0.360 \\
\hline Tanialum & 0.0157 & 0.0046 & $0 \%$ & 0 \\
\hline Indium & 0.0016 & 0.00047 & $60 \%$ & 0.00026 \\
\hline Vanadium & 0.0002 & 0.00 & $0 \%$ & 0 \\
\hline Beryllium & 0.0157 & 0.0046 & $0 \%$ & 0 \\
\hline
\end{tabular}


Journal And Confrence Paper On (Enviornment) E-Waste Management

\begin{tabular}{|c|c|c||c|c|}
\hline Gold & 0.0016 & 0.00047 & $99 \%$ & 0.00043 \\
\hline Europium & 0.0002 & 0.00 & $0 \%$ & 0 \\
\hline Tritium & 0.0157 & 0.00 & $0 \%$ & 0 \\
\hline Ruthenium & 0.0016 & 0.00047 & $80 \%$ & 0.00035 \\
\hline Cobalt & 0.0157 & 0.0047 & $85 \%$ & 0.00363 \\
\hline Palladium & 0.0003 & 0.000077 & $95 \%$ & 0.000077 \\
\hline Manganese & 0.0315 & 0.01 & $0 \%$ & 0 \\
\hline Silver & 0.0189 & 0.0156 & $98 \%$ & 0.00504 \\
\hline Antimony & 0.0094 & 0.00 & $0 \%$ & 0 \\
\hline Bismuth & 0.0063 & 0.00 & $0 \%$ & 0 \\
\hline Chromium & 0.0063 & 0.00 & $0 \%$ & 0 \\
\hline Cadmium & 0.0094 & 0.00 & $0 \%$ & 0 \\
\hline Selenium & 0.0016 & 0.00047 & $70 \%$ & 0.0003 \\
\hline Niobium & 0.0002 & 0.00045 & $0 \%$ & 0 \\
\hline Yttrium & 0.0002 & 0.00 & $0 \%$ & 0 \\
\hline Mercury & 0.0022 & 0.00 & $0 \%$ & 0 \\
\hline Arsenic & 0.0013 & 0.00 & $0 \%$ & 0 \\
\hline Silica & 24.8803 & 6.77 & $0 \%$ & 0 \\
\hline
\end{tabular}

Recoverable Quantity of Materials in a Television:-

\begin{tabular}{|c||c||c|}
\hline Elements & \% by weight & Recoverable Weight of element (Kg) \\
\hline \hline Aluminium & 1.2 & 0.4344 \\
\hline \hline Copper & 3.4 & 1.2308 \\
\hline \hline Lead & 0.2 & 0.0724 \\
\hline \hline Zinc & 0.3 & 0.1086 \\
\hline \hline Nickel & 0.038 & 0.0138 \\
\hline \hline Iron & 12 & 4.344 \\
\hline \hline Plastic & 26 & 9.412 \\
\hline \hline Glass & 53 & 19.186 \\
\hline \hline Silver & & 0.000724 \\
\hline \hline Gold & & 0.000362 \\
\hline \hline
\end{tabular}

TELEVISION COMPONENTS:-

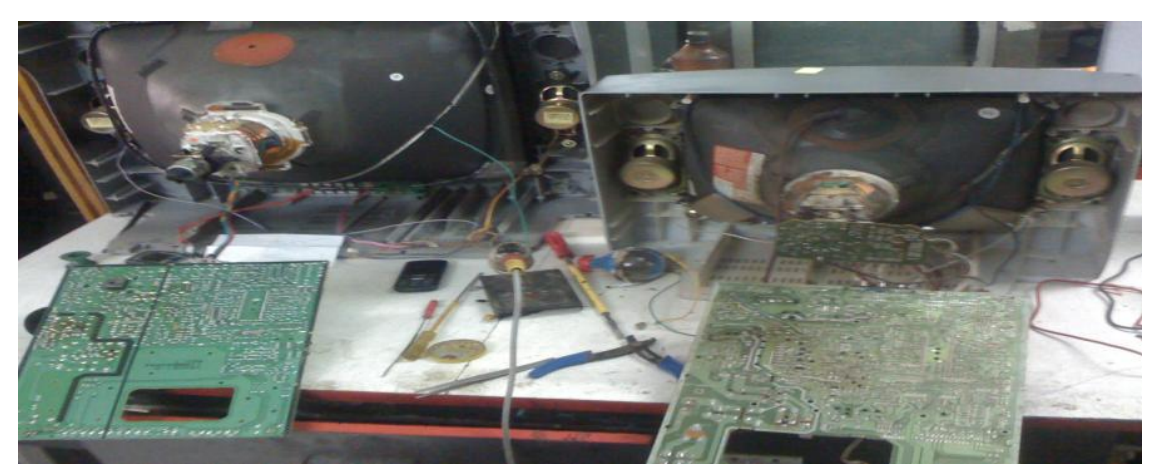




\section{CHAPTER}

ENVIRONMENTALLY SOUND TREATMENT TECHNOLOGY

\section{Environmentally sound E-waste treatment technologies:-}

* Environmentally sound E-waste treatment technologies are used at three levels as described below:

1. 1st level treatment

2. 2nd level treatment

3. 3rd level treatment

Analysis:-

All the three levels of e-waste treatment are based on material flow. The material flows from 1st level to 3rd evel treatment. Each level treatment consists of unit operations, where e-waste is treated and out put of 1 st level treatment serves as input to 2nd level treatment. After the third level treatment, the residues are disposed of either in TSDF or incinerated. The efficiency of operations at first and second level determines the quantity of residues going to TSDF or incineration. The simplified version of all the three treatments is shown in figure

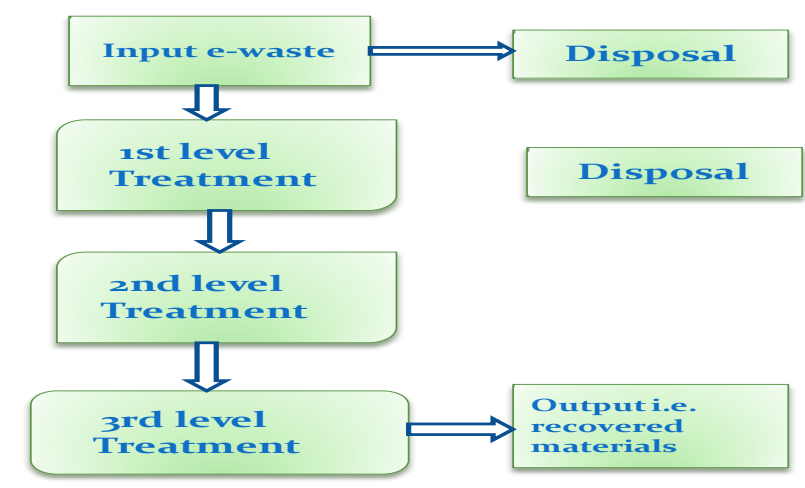

\section{1st Level Treatment:-}

Input: e-waste items like TV, refrigerator and Personal Computers (PC) Unit Operations: There are three units operations at first level of e-waste treatment

1. Decontamination : Removal of all liquids and Gases

2. Dismantling -manual/mechanized breaking

3. Segregation

All the three unit operations are dry processes, which do not require usage of water.

\section{Decontamination}

The first treatment step is to decontaminate e-waste and render it nonhazardous. This involves removal of all types of liquids and gases (if any) under negative pressure, their recovery and storage.

\section{Dismantling}

The decontaminated e-waste or the e-waste requiring no decontamination are dismantled to remove the components from the used equipments. The dismantling process could be manual or mechanized requiring adequate safety measures to be followed in the operations.

\section{Segregation}

After dismantling the components are segregated into hazardous and nonhazardous components of e-waste fractions to be sent for 3rd level treatment.

Output:

1. Segregated hazardous wastes like CFC, Hg Switches, batteries andcapacitors

2. Decontaminated e-waste consisting of segregated non-hazardous Ewastelike plastic, CRT, circuit board and cables

\section{2nd Level Treatment:-}

Input: Decontaminated E-waste consisting segregated non hazardous e-waste like plastic, CRT, circuit board and cables.

Unit Operations: There are three unit operations at second level of E-waste treatment

1. Hammering

2. Shredding

3. Special treatment Processes comprising of 
(i) CRT treatment consisting of separation of funnels and screen glass.

(ii) Electromagnetic separation

(iii) Eddy current separation

(iv) Density separation using water

\section{Process:-}

The two major unit operations are hammering and shredding. The major objective of these two unit operations is size reduction. The third unit operation consists of special treatment processes. Electromagnetic and eddy current separation utilizes properties of different elements like electrical conductivity, magnetic properties and density to separate ferrous, non ferrous metal and precious metal fractions. Plastic fractions consisting of sorted plastic after $1^{\text {st }}$ level treatment, plastic mixture and plastic with flame retardants after second level treatment, glass and lead are separated during this treatment. The efficiency of this treatment determines the recovery rate of metal and segregated E-waste fractions for third level treatment. The simplified version of this treatment technology showing combination of all three unit operations is given in Figur

Process flow of Non CRT hased e-waste treatment:-

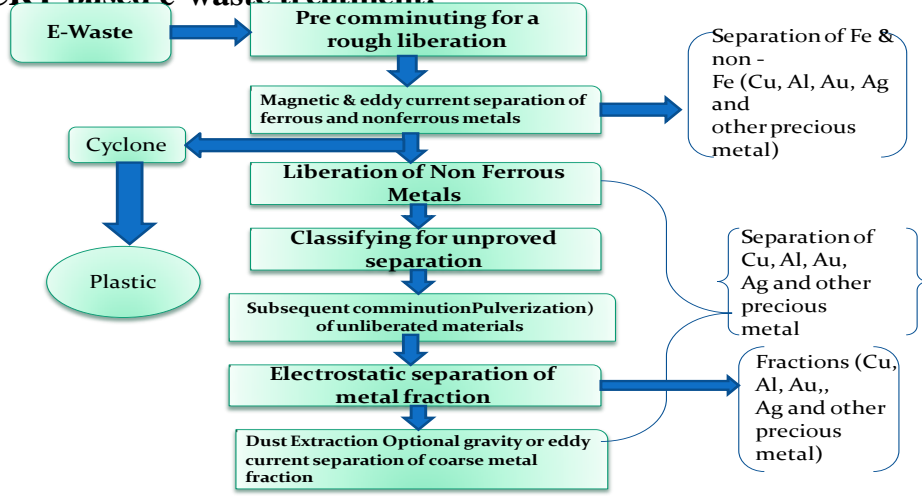

The efficacy of the recycling system is dependent on the expected yields/output of the recycling system. The expected yields/ output from therecycling system are dependent on the optimization of separation parameters. These parameters are given below:
$>\quad$ Particle size
$>\quad$ Particle shape
$>\quad$ Feeding rate/ RPM
$>\quad$ Optimum operations

Figure shows the non- ferrous metal distribution (which forms the backbone of financial viability of recycling system) as a function of size range for PC scrap. It can be seen that aluminum is mainly distributed in the coarse fractions $(+6.7 \mathrm{~mm})$, but other metals are mainly distributed inthe fine fractions $(-5 \mathrm{~mm})$.

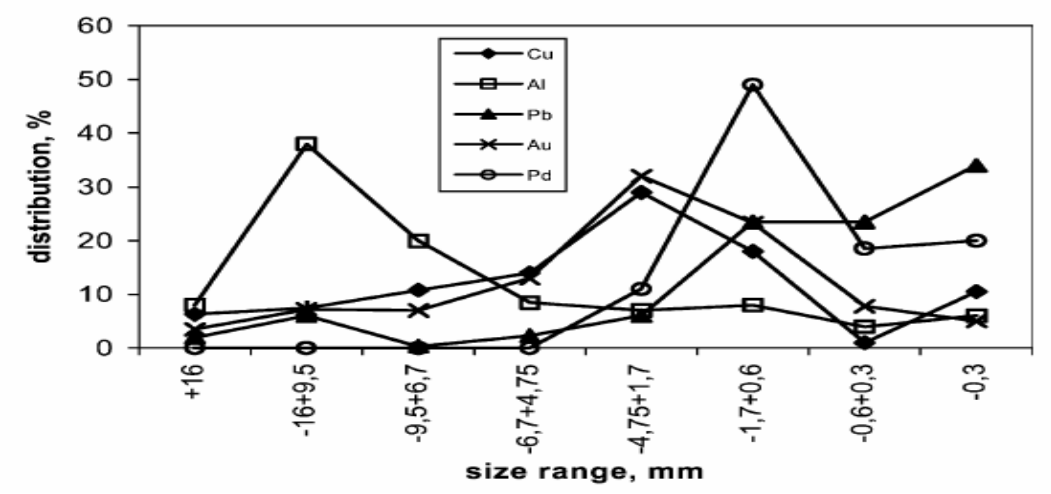

Scrap

\section{Non- Ferrous Metal Distribution Vs Size range for PC}

Size properties are essential for choosing an effective separation technique. Therefore, eddy current separator is best for granular nonferrous materials having size greater than $5 \mathrm{~mm}$. The eddy current separation will ensure better separation of $\mathrm{Al}$ fraction in comparison to fraction containing $\mathrm{Cu}, \mathrm{Ag}$ and $\mathrm{Au}$. 
Journal And Confrence Paper On (Enviornment) E-Waste Management

Particle shape is dependent on comminuting and separation. Since hammer mills and screens will be used in the proposed technology, the variations are expected to be the same as that of Best Available Technology (BAT).

The feeding rate can be optimized based on the speed and width of the conveyor

CRT treatment technology:-

The salient features of CRT treatment technology are given below.

1. CRT is manually removed from plastic/ wooden casing.

2. Picture tube is split and the funnel section is then lifted off the screen section and the internal metal mask can be lifted to facilitate internal phosphor coating.

3. Internal phosphor coating is removed by using an abrasive wire brush and a strong vacuum system to clean the inside and recover the coating. The extracted air is cleaned through an air filter system to collect the phosphordust.

Different types of splitting technology used are given below.

$>\quad$ NiChrome hot wire cutting:- A NiChrome wire or ribbon is wrapped round a CRT and electrically heated for at least 30 seconds to causes a thermal differential across the thickness of the glass. The area is then cooled (e.g. with a water-soaked sponge) to create thermal stress which results in a crack. When this is lightly tapped, the screen separates from the funnel section.

$>$ Thermal shock:- The CRT tube is subjected to localized heat followed by cold air. This creates stress at the frit line where the leaded funnel glass is joined to the unleaded panel glass and the tube comes apart.

Laser cutting:- A laser beam is focused inside and this heats up the glass. It is immediately followed by a cold water spray that cools the surface of the glass and causes it to crack along the cut line.

Diamond wire method:- In this method, a wire with a very small diameter, which is embedded with industrial diamond is used to cut the glass as the CRT is passed through the cutting plane.

$>\quad$ Diamond saw separation:- Diamond saw separation uses either wet or dry process. Wet saw separation involves rotating the CRT in an enclosure while one or more saw blades cut through the CRT around its entire circumference. Coolant

is sprayed on to the surface of the saw blades as they cut. This is to control temperature and prevent warping.

Water-jet separation:- This technology uses a high-pressure spray of water containing abrasive, directed at the surface to be cut. The water is focused through a single or double nozzle-spraying configuration set at a specific distance.

3rd Level E-waste Treatment:-

The 3rd level E-waste treatment is carried out mainly to recover ferrous, nonferrous metals, plastics and other items of economic value. The major recovery operations are focused on ferrous and non ferrous metal recovery, which is either geographically carried out at different places or at one place in an integrated facility. The following sections describe the unit operations, processes, available technology and environmental implications.

Input/ Output and Unit Operations:-

The input, output and unit operations at 3rd level treatment are described in table

\begin{tabular}{|l|l|l|}
\hline \multicolumn{1}{|c|}{ Input/ WEEE Residues } & \multicolumn{1}{c|}{$\begin{array}{c}\text { Unit Operation/ Disposal/ } \\
\text { Recycling Technique }\end{array}$} & Output \\
\hline \multicolumn{1}{|c|}{ Sorted Plastic } & \multicolumn{1}{|c|}{ Recycling } & \multicolumn{1}{c|}{ Plastic Product } \\
\hline Plastic Mixture & Energy Recovery/ Incineration & Energy Recovery \\
\hline Plastic Mixture with BFR & Incineration & Energy Recovery \\
\hline CRT & Breaking/ Recycling & Glass Cullet \\
\hline Lead bearing residue & Secondary Lead Smelter & Lead \\
\hline Ferrous metal scrap & Secondary steel/ iron recycling & Iron \\
\hline Non Ferrous metal Scrap & $\begin{array}{l}\text { Secondary copper and } \\
\text { aluminum smelting }\end{array}$ & Copper/ Aluminum \\
\hline Precious Metals & Au/ Ag separation & Gold/ Silver \\
\hline $\begin{array}{l}\text { Batteries (Lead, Acid/ } \\
\text { Nickel metal Hydride (Ni- } \\
\text { MH) and Li - ion }\end{array}$ & $\begin{array}{l}\text { Lead recovery and smelting } \\
\text { remelting and separation }\end{array}$ & Lead \\
\hline CFC & Recovery/ Reuse / Incineration & CFC/ Energy recovery \\
\hline
\end{tabular}

The description of some of the 3rd level WEEE/ E-waste processes are described below. 
Plastic Recycling:-

There are three different types of plastic recycling options i.e. chemical recycling, mechanical recycling and thermal recycling. All the three processes are shown in figure In chemical recycling process, waste plastics are used as raw materials for petrochemical processes or as reductant in a metal smelter. In mechanical recycling process, shredding and identification process is used to make new plastic product. In thermal recycling process, plastics are used as alternative fuel. The two major types of plastic resins, which are used in electronics, are "thermosets" and "thermoplastics". Thermosets are shredded and recycled because they cannot be re-melted and formed into new products, while thermoplastics can be re-melted and formed into new products.

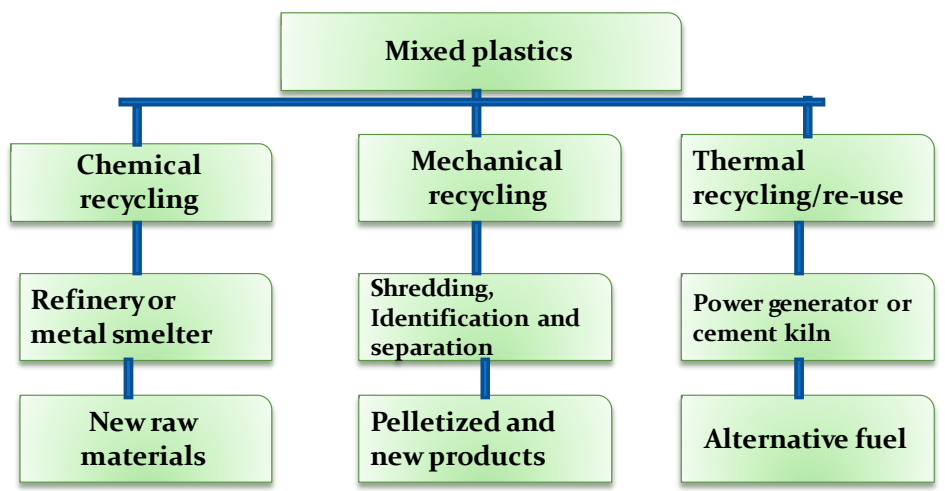

\section{Recycling options for managing plastics from end-of-life Electronics}

In thermal recycling process, plastics are used as fuel for energy recovery. Since plastics have high calorific value, which is equivalent to or greater than coal, they can be combusted to produce heat energy in cement kilns.

Chemical Recycling Process:- Chemical recycling process is shown in figure 6.6. This process was developed by the Association of Plastic Manufacturers in Europe (APME). The different steps in this process are given below.

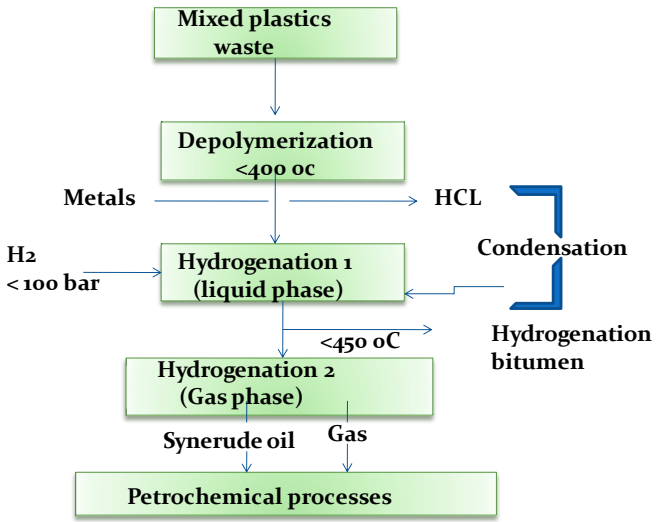

De-polymerization of plastics and conversion processes

\section{PROCESS:-}

1. Mixed plastic waste is first de-polymerized at about $350-400^{\circ} \mathrm{C}$ and dehalogenated $(\mathrm{Br}$ and $\mathrm{Cl})$. This step also includes removal of metals

.2. In hydrogenation unit 1 , the remaining polymer chains from depolymerised unit are cracked at temperatures between $350-400^{\circ} \mathrm{C}$ and hydrogenated at pressure greater than 100 bar. After hydrogenation, the liquid product is subjected to distillation and left over inert material is collected in the bottom of distillation column as residue, hydrogenation bitumen.

3. In hydrogenation unit 2, high quality products like off gas and sync rude are obtained by hydro-treatment, which are sent to petrochemical process.

\section{* Metals Recycling:-}

Metals recycling have been described below in terms of lead recycling, copper recycling and precious metals recycling. After sorting of metal fractions at 2 nd level e-waste treatment, they are sent to metal recovery facilities. These metal recovery facilities use the following processes to recover metals. 
Lead Recovery:- Reverberatory furnace and blast furnace are used to recover lead from e-waste fraction. The process is shown in figure 6.7 and involves the following steps.

\section{Processes flow for secondary lead recovery}

\section{PROCESS:-}

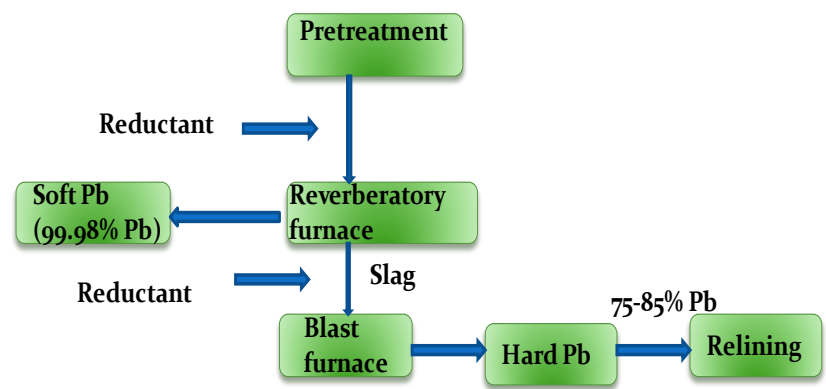

1. A reverberatory furnace is charged with lead containing materials and reductants. In this furnace, the reduction of lead compounds is carried out to produce lead bullion and slag. Lead bullion is $99.9 \%$ while slag contains $60-70 \%$ wt. \% lead and a soft (pure) lead product. The following reactions occur in the reverberatory furnace.

$\mathrm{PbO}+\mathrm{C} \mathrm{Pb}+\mathrm{CO}$

$2 \mathrm{Sb}+3 \mathrm{PbO} 3 \mathrm{~Pb}+\mathrm{Sb} 2 \mathrm{O} 3$

$2 \mathrm{As}+3 \mathrm{PbO} 3 \mathrm{~Pb}+\mathrm{As} 2 \mathrm{O} 3$

$\mathrm{Sn}+2 \mathrm{PbO} 2 \mathrm{~Pb}+\mathrm{SnO} 2$

2. Slag in reverberatory furnace is continuously tapped onto a slag caster. It consists of a thin, fluid layer on top of the heavier lead layer in the furnace.

3. Lead bullion is tapped from the furnace when the metal level builds up to a height that only small amounts of lead appear in the slag.

4. Lead is recovered from the slag by charging it in blast furnace along with other lead containing materials and fluxing agents like iron and limestone.

5. Hard lead is recovered from the blast furnace, which contains $75-85$ wt. \% Pb and 15-25 wt. \% Sb. Slag contains 1-3\% lead. Slag contains $\mathrm{CaO}, \mathrm{SiO} 2$ and $\mathrm{FeO}$.

6. Flue gas emissions from reverberatory furnace are collected by bag house and feedback into the furnace to recover lead. Slag from blast furnace is disposed of in hazardous waste landfill sites.

Technology Currently Used in India:- For non CRT E-waste, the two E-waste treatment facilities in India use the following technologies.

1. Dismantling

2. Pulverization/ Hammering

3. Shredding

4. Density separation using water

The CRT treatment technology as used by CRT manufacturer in India for discarded CRT's, is shown in Figure

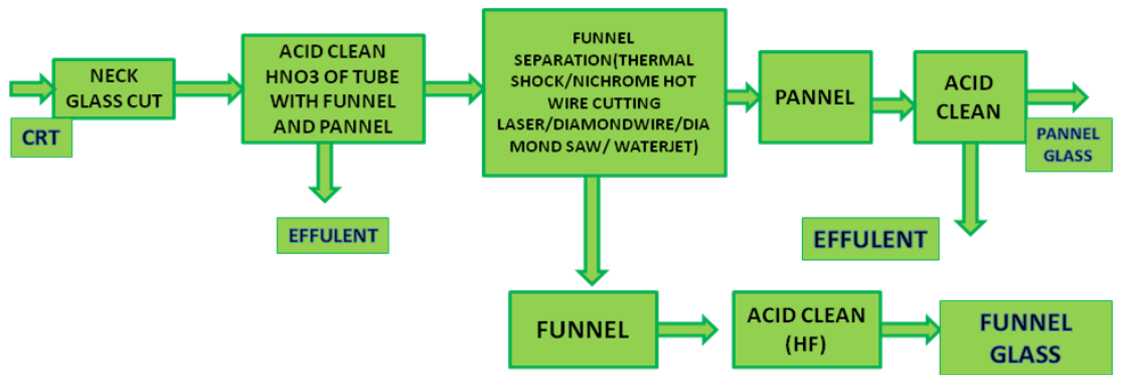

\section{E-WASTE RECYCLING \& TREATMENT FACILITY}

\section{CHAPTER}

for establishment of E-waste Recycling \& Treatment Facility shall be in line with the existing Guidelines/best practices/requirements in India for establishing and operating "Recycling and Treatment and Disposal Facilities" for hazardous wastes. Such facilities shall be set up in the organized sector. However, the 
activities presently operating in the informal sector need to be upgraded to provide a support system for the integrated facility. This would enable to bring the non-formal sector in the main stream of the activity and facilitate to ensure environmental compliances. The proposed mechanism for the e-waste facility is only an illustrative model and details have to beworked out to develop such facilities.

Facility Operation Requirements:-

$\begin{array}{ll}\star & \text { Collection } \\ \star & \text { Storage } \\ \star & \text { Dismantling \& Segregation } \\ \star & \text { Recycling } \\ \star & \text { Treatment \& Disposal }\end{array}$

\section{Collection Systems for e-waste:-}

A producer is responsible for his products he may be involved in the establishment of the take back system for end of use electronic and electrical equipments. The producer responsibility could be either Individual or collective. Individual model requires each producer to be responsible for managing the ewaste generated by their products. The producer shall announce a take back system. The individual producers can have direct contact with dismantlers or recyclers which allows them to get back the re-usable components from their obsolete equipments. The producers can also get the data from the collector/ dismantler/recycler about the specific composition and characteristics of the products. In the case of collective producer responsibility the producer would enter into a contractual agreements with a collection agency which would be responsible for collection of the waste from the generator. The producers through the collection agency have to pay a fixed price for their products to the generator, as in the collective responsibility model. The take back system may provide free collection or provide discount on purchase of new items. This facilitates in establishing a feasible and effective collection system to enable the channelization of the e-waste to appropriate recycling facilities and increasing reuse of certain components. The economic rationale behind is to facilitate the transfer of the benefits to the consumers enabling them to get better price on the sale of used equipments.

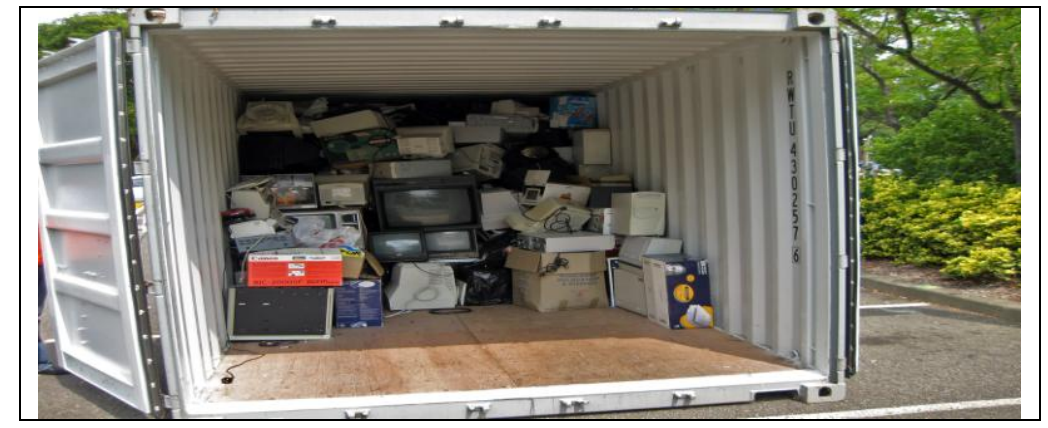

\section{Collection Systems for e-waste}

\section{* Storage areas:-}

(1) The storage areas for string the e-waste in a facility can be located within the facility - on-site storage or located at a place outside the facility - offsite storage including the ware houses. Such storage areas should be covered areas for storage of e-waste till such time that the waste is recycled or treated. The storages could also be the warehouses hired for this purpose.

(2) Appropriate containers should be used for storing different e-waste items separately and there should be no mixing of different kinds of e-waste

(3) The purpose of the weatherproof covering for storage at treatment sites is to minimize the contamination of clean surface and rain waters, to facilitate the reuse of those whole appliances and components intended for recycling and to assist in the containment of hazardous materials and fluids. The areas that are likely to require weatherproof covering will therefore include the storage areas and the treatment areas for the treating hazardous or fluid containing e-waste or whole appliances or components intended for recycling. The type of weatherproof covering required will depend of the types and quantities of waste and the storage and treatment activities undertaken. Weatherproof covering may in some circumstances simply involve a lid or cover over a container but in others it may involve the construction of a roofed building.

(4) Impermeable surfaces should be provide for appropriate areas. "Impermeable surface" means a surface or pavement constructed and maintained to a standard sufficient to prevent the transmission of liquids beyond the pavement surface. The impermeable surface should be associated with a sealed drainage system and may be needed even where weatherproof covering is used. This means a drainage system with impermeable components 
which does not leak and which will ensure that no liquid will run off the pavement other than via the system and all liquids entering the system are collected in a sealed sump.

(5) Appropriate spillage collection facilities should be provided. The spillage collection facilities include the impermeable pavement and sealed drainage system as the primary means of containment. However, spill kits to deal with spillages of oils, fuel and acids should be provided and used as appropriate.

(6) Appropriate sites must provide appropriate storage for disassembled spare parts. Some spare parts (e.g. motors and compressors) will contain oil and/or other fluids. Such parts must be appropriately segregated and stored in containers that are secured such that oil and other fluids cannot escape from them. These containers must be stored on an area with an 49impermeable surface and a sealed drainage system.

(7) Other components and residues arising from the treatment of e-waste will need to be contained following their removal for disposal or recovery. Where they contain hazardous substances they should be stored on impermeable surfaces and in appropriate containers or bays with weatherproof covering. Containers should be clearly labeled to identify their contents and must be secure so that liquids, including rainwater, cannot enter them. Components should be segregated having regard to their eventual destinations and the compatibility of the component types. All batteries should be handled and stored having regard to the potential fire risk associated with them.

\section{Storage areas:-}
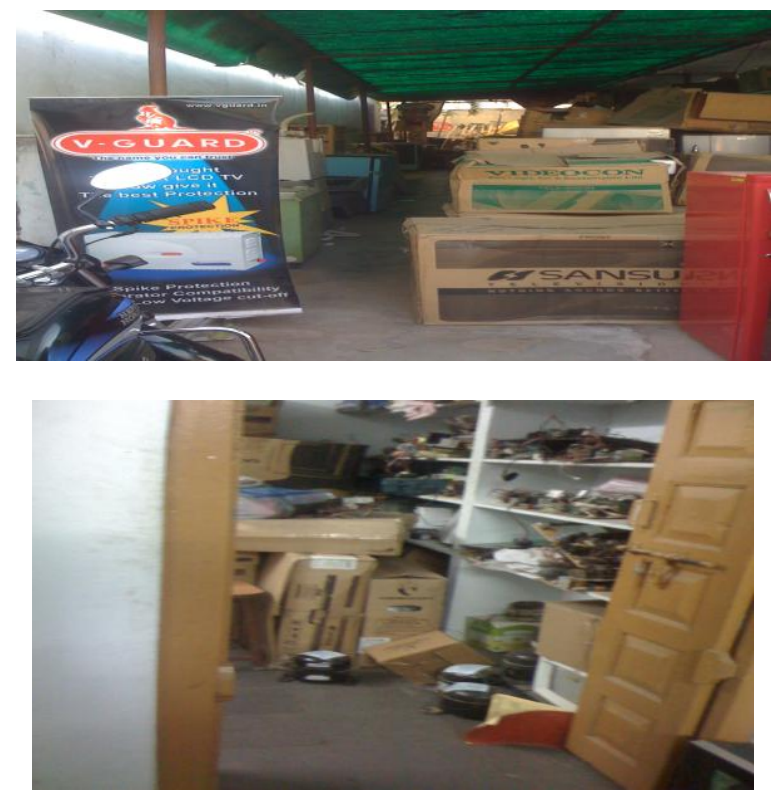

STORE ROOM

VIII.

CHAPTER

\section{STRATEGIES FOR COMBATING E- WASTE}

\section{\# LEGISLATION}

Separate legislation for dealing with waste electrical and electronic equipments to control aspects of production, recycle, reuse and disposal is need of the hour. Many countries have such laws in place. In India, draft e-Waste (Management and Handling) Rules have been published by the Ministry of Environment and Forests, Government of India on 14.5.2010.

\section{* EXTENDED PRODUCER RESPONSIBILITY (EPR)}

Traditionally, the legislative approach toward environmental problems has been one of 'command and control', largely addressing 'end-of-pipe' pollution problems. Now, the emphasis is changing towards producer responsibility whereby those who produce good sare then responsible for the environmental impacts throughout the whole of their life cycle, from resource extraction to recycling, reuse and disposal (Nnorom et.al, 2008). Implementation of EPR in the developing countries has become necessary in the light of the present high level of trans-boundary movement of e-waste into the developing countries and the absence of basic or state-of the-art facilities for sound end-of-life material/energy recovery and disposal of e-waste.

The Organization for Economic Cooperation and Development(OECD) defined EPR as "an environmental policy approach in which a producers' responsibility for a product is extended to the postconsumer stage of a products life cycle including its final disposal"

The main goals of EPR are: 
- waste prevention and reduction;

- product reuse;

- increased use of recycled materials in production;

- reduced natural resource consumption;

- internalization of environmental costs into product prices

- energy recovery when incineration is considered appropriate

Under EPR, the producer is expected to take back all electrical and electronic equipment at the end of their life.

\section{REDUCTION IN USE OF HAZARDOUS SUBSTANCES (ROHS)}

This aims at reducing the hazardous substances entering the atmosphere while dismantling the e-waste by prescribing threshold limits for use of such substances in e-waste.

\section{HOW ELECTRONICS WASTE GET RECYCLED}

Equipment Structure of Plant

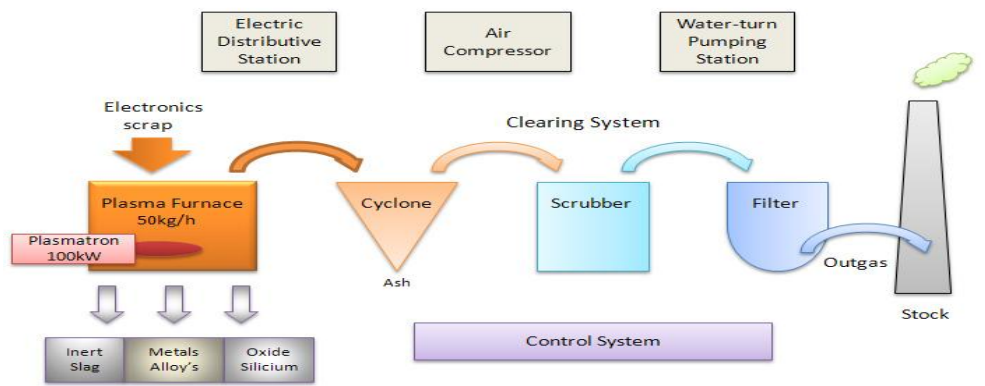

EQUIPMENT STRUCTURE OF E- WASTE PLANT

IX.

CHAPTER

FACT SHEET OF THE MAHABUBNAGAR

TOTAL E- WASTE PRODUCE FROM DIFFERENT SOURCES ARE:

Social Infrastructure

Hospitals:

60

90

Dispensaries :

Public Health Centres :
$72 \%$

PRODUCE WASTE \%

\section{Education}

High Schools :

Junior Colleges:

Degree Colleges:

Post Graduate Centres: $\quad 2 \quad 10 \%$

Engineering Colleges: $\quad 3 \quad 16 \%$

Medical Colleges: $\quad 2 \quad 41 \%$

Polytechnical Colleges: $\quad 2 \quad 10 \%$

Colleges of Education: $\quad 5 \quad 10 \%$

DIET College:

$127 \%$

\section{house holds}

(containing PC, TV, Mobile Phone etc.)

\begin{tabular}{|c|c|}
\hline Material & \% Composition (by weight) \\
\hline Mild steel & 23 \\
\hline Stainless steel & 8 \\
\hline Glass & 27 \\
\hline Plastics & 27 \\
\hline Copper & 3 \\
\hline Aluminium & 3 \\
\hline Other materials & 8 \\
\hline
\end{tabular}




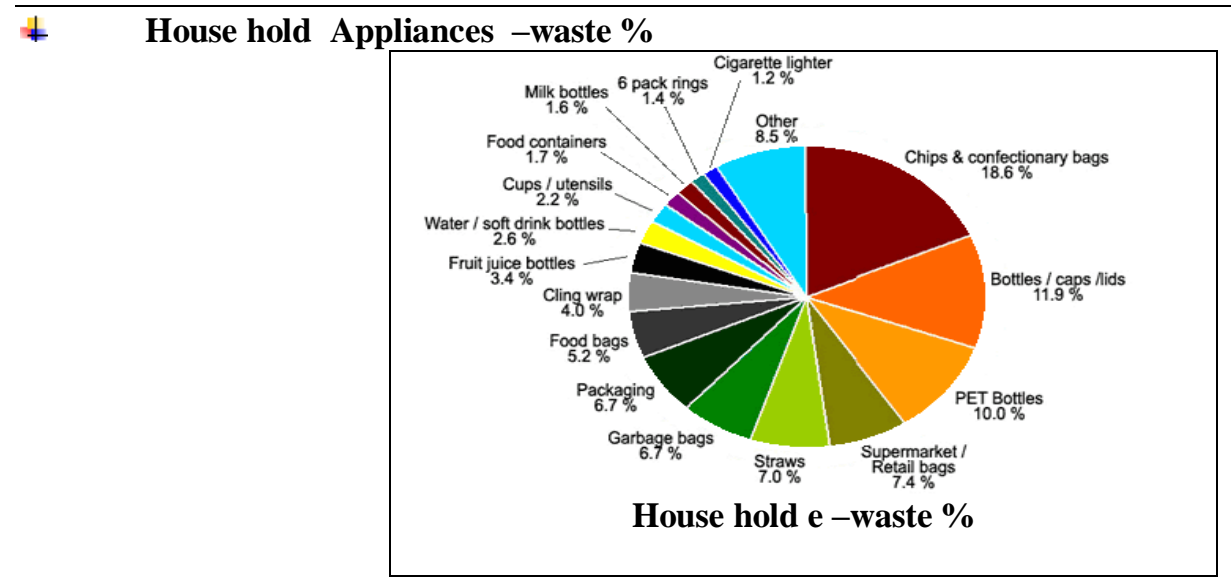

These are the household appliances where we use in our daily life and according to time period of the product it is workable and then it is consider as a waste and the minimum and maximum products percentage are shown in pie chart which is given above.

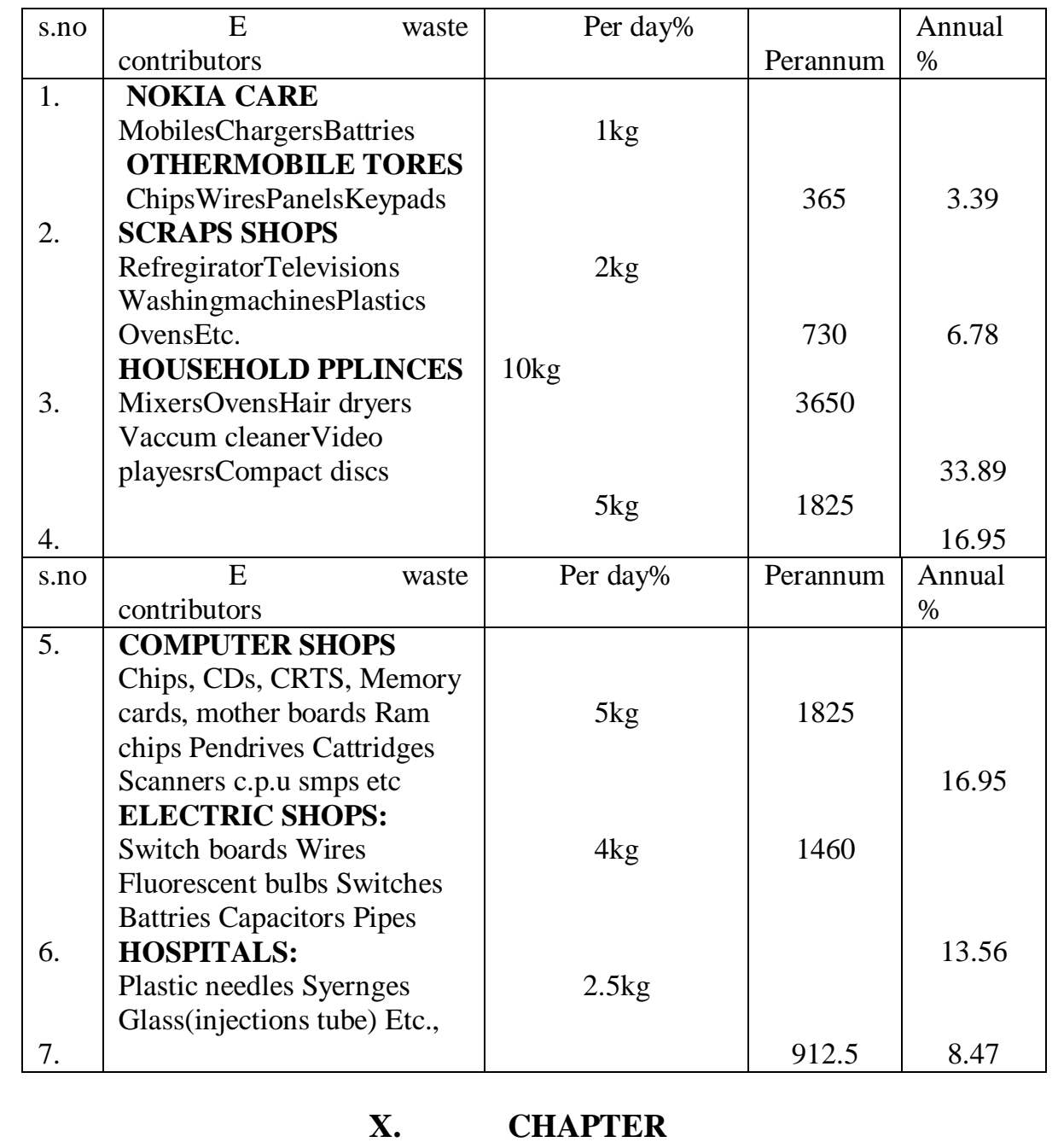

\section{CONCLUSION}

* Electronic and electrical equipments cannot be avoided in today's world. So also is the case of waste electronic and electrical equipments.

* As long as this is a necessary evil, it has to be best managed to minimize its adverse impacts on environment.

* Through innovative changes in product design under EPR( EXTENDED PRODUCER

RESPONSIBILITY), use of environmentally friendly substitutes for hazardous substances, these impacts can be mitigated. 
* A legal framework has to be there for enforcing EPR, RoHS for attaining this goal. Adoption of environmentally sound technologies for recycling and reuse of e-waste along with EPR and RoHS offers workable solution for environmentally sound management of e-waste.

* Manufacturers \& Suppliers to set goals for reducing electronic waste.Encourage them to buy back old electronic products from consumers Disposing bulk e-waste only through authorized recyclers Send nontradable e-waste to authorized private developers for final disposal.

- Store the electronics products in store houses which are not in use this is one of the technique to protect environment from hazardous waste gases.

* So, we have surveyed in mahabubnagar that how much percentage of e-waste is getting disposed per annum.

* From different industries like mobile stores, electric shops. Household products, scrap shops, computers shops etc.,

* It is our duty to protect our environment from the hazardous waste to better life of further generation.

* It can also protectable to whole ecosystem.

* Todays electronics gadgets are tommrows E- waste

\section{References}

[1] Bandhopadhyay, A. (2010) "Electronic Waste Management: Indian Practices and Guidelines" International Journal of Energy and Environment 1(5) pp. 193-807

[2] Basel Convention on the Control of Transboundary Movement of Hazardous Wastes and Their Disposal - Document accessed in $10 / 2010$

[3] Sathish Sinha (2006) E-waste Time to Act Now - Toxic Alert, accessed in 10/2010

[4] Radha Gopalan, 2002, A Study on the Indian IT Sector from nautilus.org

[5] Scraping the Hi-tech Myth - Computer Waste in India, 2003, Toxics Link

[6] Indian Institutes of Materials Management/Publications

[7] Environmentally Sound options for E-WASTES Management. By: *Ramachandra T.V.., *Saira Varghesek. Published By: Envis Journal of Human Settlements, March 2009.

[8] Global E-Waste Management \& Services (GEMs), Hyderabad.

[9] National Environment Agency of Singapore (NEA). March 1998. Hazardous Waste (Control of Export, Import and Transit) Regulations.

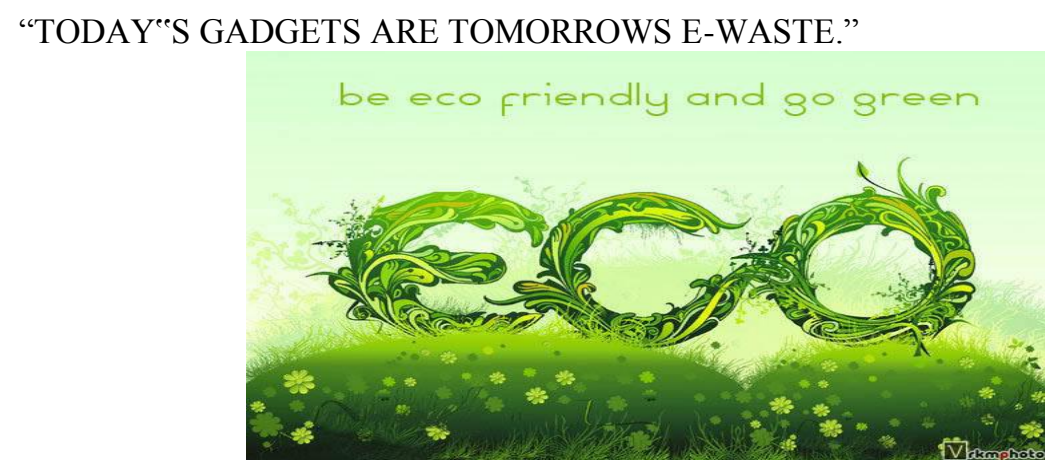

Protect Our Environment From This Hazardous Waste For Better Life For All 